\title{
The Emerging Role of Universities in Collective Impact Initiatives for Community Benefit
}

\author{
Jason Smith, Lynn E. Pelco, and Alex Rooke
}

\begin{abstract}
Universities are increasing their efforts to more clearly demonstrate their social value. This article illustrates how higher education administrators can incorporate collective impact partnerships in their community benefit strategies. The article explores two of the more familiar paradigms for community benefit—community engagement and anchor institution. Collective impact principles and practices are then presented. Finally, a case study provides a tangible example of how one university's role in a collective impact initiative transitioned in response to the community. We end the article with ten takeaways and an invitation for higher education administrators to identify their own learning and action steps that can help shift focus from proving to improving their institution's value to the community.
\end{abstract}

Keywords: Community engagement; anchor institutions; partnership; collective impact

\section{Introduction}

Administrators in today's urban and metropolitan universities are feeling pressure to demonstrate tangible value to their host city and region (Starke, Shenouda, \& Smith-Howell, 2017). Urban serving universities (USUs) have been a vital resource to their regions, but have not always publically demonstrated clear evidence of their regional contributions. As knowledge institutions, universities are well-equipped to study and report on their positive impact on the community. Understanding, documenting, communicating, and better leveraging internal assets is important work. However, these approaches may not fully satisfy community leaders' requests to demonstrate the value of an USU to a region. The university's neighbors may not just be asking for the university to prove, but also to improve.

Many of America's cities have experienced tremendous resurgence in recent years—renewals that metropolitan universities have helped to stimulate (Trani, 2008). These cities have reasserted themselves, in ways that may require a change in the roles that universities play in their communities and how they partner with the community (Cantor, Englot, \& Higgins, 2013). This article first provides a brief overview of how universities have responded to the need to define their community benefit. The article then describes three community-university partnership paradigms: (a) the community engagement model, (b) the anchor organization model, and (c) the collective impact model. We then provide a case study that explores Virginia Commonwealth University's role in the resurgence of Richmond and the university's leadership in the community engagement and anchor organization paradigms. The case study also describes the university's pioneering work as a replication site for an emerging cradle-to-career community benefit framework. The narrative concludes with an invitation to higher education leaders to identify ways to improve their own institution's community benefit efforts based on their reflection on this article. 


\section{Historic Roles of Urban Serving Universities}

Although urban serving universities are geographically situated within urban communities, for the past half century they have typically co-existed alongside these communities rather than collaborated with them (Cantor \& Englot, 2014). In the early 1900s, American higher education gave priority to knowledge creation over solving social problems (Fitzgerald, Bruns, Sonka, Furco, \& Swanson, 2012). Beginning in the 1940s and 1950s, higher education in the United States grew rapidly with the passage of the Servicemen's Readjustment Act of 1944 (i.e., the GI Bill). Universities struggled to keep up with growing student enrollments. They decentralized administrative and teaching tasks and hired large numbers of new faculty instructors throughout the 1950s and 1960s.

These faculty were increasingly viewed as content experts within narrow areas of specialization that had little application to social problems and were disconnected from community context and input (Fitzgerald, et al., 2012). The Cold War and the country's race to space led many faculty members into research laboratories and away from classrooms and communities. As these trends continued throughout the 1970s and 1980s, class-enrollment size increased. Funding for public universities began to decline in the recession of the 1990s, as state budgets shrank and elected officials shifted their view of higher education from a public good to an individual benefit (Hensley, Galilee-Belfer, \& Lee, 2013).

By the late 1990s, university presidents, faculty members, and students began to question their university's disconnectedness from its local community (Fitzgerald et al., 2012). Relationships between urban serving universities and the communities that surrounded them were often strained, as these universities had expanded during the previous decades by buying up real estate contiguous to their campuses and displacing local, often low-income, residents (Cantor, Englot, \& Higgins, 2013). Urban serving universities around the country began to reach back out to the communities that surrounded them with community engagement initiatives during the 1990s and 2000s. Because universities themselves still operated in a decentralized manner, early community engagement efforts often developed in silos, with individual academic departments and schools launching their own initiatives and programs.

\section{Three Paradigms for University-Community Partnership}

This section describes three approaches universities may employ to provide value to their host city and region, including community engagement, anchor institution, and collective impact. Each of the approaches have their own emerging body of practice and literature. One of the contributions of this article is describing the paradigm shifts in university community benefit represented by the emergence of community engagement, anchor institution, and collective impact paradigms. The authors assert that university administrators may simultaneously incorporate ideas from multiple paradigms or may narrowly align with one. Further, the authors believe that no one paradigm is more important than the others, and that the problem and desired result must inform the approach. Misalignment of the felt problem and the selected approach is likely to cause stakeholder dissatisfaction. When dissatisfaction occurs, institutions may be tempted to lurch from one paradigm to another or to tinker at the edges of their current approach. 
The authors caution that these types of responses can prevent institutions from adopting a critical problem-solving perspective that enables stakeholders to leverage value from all three paradigms.

\section{Community Engagement Paradigm}

The community engagement movement emerged over the past three decades. The movement has come to include multiple activities such as service-learning, civic engagement, and communityengaged research. The founding of Campus Compact in 1985 represents a starting point for an emphasis on community engagement in higher education (Butin \& Seider, 2012). By the 2010s, much had been learned about successful community-campus partnerships. Reciprocity, exchanging things or services with others for mutual benefit, became an organizing community engagement principle. Administrators began to express their interest in creating institutionallevel (versus academic department-level) approaches to university-community partnerships. Universities created centralized offices of community engagement to lead, coordinate, and assess the impact of integrated, cross-disciplinary, and institutional-level efforts called for by the community.

The Carnegie Foundation for the Advancement of Teaching institutionalized the concept of community engagement by including it in their higher education classification cycle. Carnegie defines community engagement as "the collaboration between institutions of higher education and their larger communities (local, regional/state, national, global) for the mutually beneficial exchange of knowledge and resources in a context of partnership and reciprocity” (https://compact.org/initiatives/carnegie-community-engagement-classification/). The term community engagement, even if used consistently across units within an institution, can be applied to a wide range of activities that may not meet the technical definition (Starke, Shenouda \& Smith-Howell, 2017). This ambiguity makes a challenge for mapping, measuring, prioritizing results, and assessing value.

Community engagement offices focused their early assessment efforts on documenting the impact of community partnerships on outcomes traditionally valued by universities, such as the number and quality of scholarly products produced, as well as student learning outcomes. First generation community engagement research results suggested that some approaches were having a positive impact on important student outcomes, such as retention and degree completion (Lockeman \& Pelco, 2013). Only in very recent years have universities begun to think critically about how best to insure that university-community collaborations benefit community as well as university stakeholders.

Signs of internal malaise were beginning to be seen within the movement by the 2010s (Butin \& Seider, 2012). The lack of conceptual focus, limited rigorous research, and uncertain community impact all contributed to current challenges within the movement. The higher education community responded in a few ways, by: (a) continuing to position community engagement as a broad umbrella; (b) attempting to re-ignite the movement with clearer conceptual clarity and goals; (c) institutionalizing community engagement in certificates, minors, and degrees; and (d) shifting investment to other community benefit paradigms. 


\section{Anchor Institution Paradigm}

The anchor institution paradigm of university-community partnerships, like the community engagement paradigm, developed during the early decades of the $21^{\text {st }}$ century. Urban-serving universities are described as anchor organizations because they are deeply rooted in their community. In 2002, in a CEOs for Cities report, Michael Porter used the label "anchor institutions" as part of a call to action. College and university leaders needed to develop strategic plans to catalyze economic development in their surrounding communities (CEOs for Cities with Living Cities, 2010). According to the Democracy Collaborative, “Anchor institutions are placebased entities, such as universities and hospitals that are tied to their surroundings by mission, invested capital, or relationships to customers, employees, and vendors” (Dubb, McKinley, \& Howard, 2013, p. 2). Early university anchor institution efforts placed a heavy emphasis on real estate development and the development of retail and public spaces where they intersected with the neighboring community (CEOs for Cities with Living Cities, 2010).

The anchor institution movement often defines itself in contrast to the community engagement movement rather than as a complement to it. In their paper titled, The Anchor Dashboard: Aligning Institutional Practice to Meet Low-Income Community Needs, Dubb, McKinley and Howard (2013) called for the creation of a new anchor mission community of practice. The authors state that, "an anchor strategy is more than the sum of individual community engagement programs; it is a mission developed to address tenacious community challenges, and implemented to permeate an institution's culture and change the way it does business" (Dubb, McKinley \& Howard, 2013, p. 1). Over time, universities began to hire and purchase locally, to explore commercialization of their research, and to engage with the broader community's economic development plans (CEOs for Cities with Living Cities, 2010).

The anchor institution paradigm developed as a critique of the lack of institutional-level goals and indicators of community impact in the community engagement paradigm. Business transactions were quantifiable, targets could be set, and social value was easier to communicate to local business leaders and elected officials. Anchor institution initiatives appeared to move beyond the measurement of isolated programs and research projects to providing a framework for aligning institutional assets. Anchor institution paradigm advocates believed their paradigm fundamentally questioned the substantial investment some institutions had made in "dollars and personnel toward discrete community programs" and stated that their paradigm was qualitatively different (Dubb, McKinley, \& Howard, 2013, p. 1). Central to the anchor institution movement is the focus on the use of two forms of metrics: (a) indicators of community well-being to focus institutional investments; and (b) measures that assess the institution's effort to improve the indicators. Advocates of the anchor institution paradigm acknowledge that an anchor institution is not the only factor contributing to changes in community indicators. Yet, a key focus of the paradigm is to help internal decision makers align individual institutional efforts, so that these efforts might better provide and demonstrate value to the community. Collective Impact Paradigm

Beginning in 2011, Kania and Kramer introduced the concept of collective impact and defined it as "the commitment of a group of important actors from different sectors to a common agenda for solving a specific social problem”. The collective impact movement in begins with the 
premise that the efforts of individual organizations and isolated programs are insufficient to address complex social problems. A focus on implementing isolated programs can obscure the need to fundamentally change the system, address policy, or improve practice. Because the collective impact paradigm is less well known, we define and describe it below detail.

Both the higher education and nonprofit sectors frequently operate using an isolated impact approach (Kania \& Kramer, 2011). Individual organizations or research teams seek to demonstrate value by developing solutions for complex social problems that can then be scaled by expanding research-informed programs and interventions. National emphasis on randomized controlled trials (RCT) as the gold standard for research also contributed to a higher education culture that seeks solutions that work in a closely controlled environment, but not necessarily in the complex community settings. According to Kania and Kramer (2013), "the greatest obstacle to success is that practitioners embark on the collective impact process expecting the wrong type of solutions” (p. 2).

The success of collective impact initiatives depends on the existence of five conditions: (a) a common agenda; (b) shared measurement; (c) mutually reinforcing activities; (d) continuous communications; and (e) backbone support (Hanleybrown, Kania, \& Kramer, 2012). A common agenda begins with a shared understanding of the problem and a common way of solving it, which is developed through agreed-upon action from all participants (Kania \& Kramer, 2013). Power dynamics associated with resources, privileged forms of knowledge, credentials, and influence can create conditions within which anchor organizations may believe there is a common agenda when community partners do not share the vision. Shared measurement includes agreed upon indicators and targets, as well as ways to measure efforts to ensure mutual accountability (Hanleybrown, Kania, \& Kramer, 2012).

A focus on business measures and traditional forms of research might drive initiatives towards solutions that do not take into account the system in which the solution will be implemented or the practical measurement strategies that will be used to gauge improvement. This disconnect can block the development of mutually reinforcing activities. Continuous communication strategies that are accessible to all partners build trust, insure a common purpose, align motivations, and create accountability for action commitments. The language and communication styles used in higher education, the business sector, social sector, and in local communities vary greatly, requiring ongoing translation of information to connect it to meaning frameworks for all partners.

Backbone supports, the fifth condition, refer to facilitation, data systems and analysis, communication support, highly structured problem solving methods, and the administrative functions that are needed to effectively coordinate the participation of multiple organizations. Turner, Merchant, Kania and Martin (2012) described six critically important functions that backbone supports facilitate: (a) guiding vision and strategy; (b) supporting aligned activity; (c) establishing shared measurement practices; (d) building public will; (e) advancing policy; and (f) mobilizing funding. By necessity or by design, backbone supports can be addressed through either a centralized (i.e., located in a single organization) or decentralized (i.e., located in multiple organizations) model. 
Surman (2006, 2008), urged collaborative partnerships "NOT to legally incorporate in any way. This....undermines the power dynamic of the group and creates an entity that will innately want to build itself to compete with its own members" (p. 10). Rather than arguing for a single backbone organization, Surman emphasized the importance of several organizing principles: (a) action teams or constellations are formed to address a problem and are creatively destroyed when the work is accomplished; (b) leadership is shifted between partners on a project-by-project basis; (c) a stewardship group is created that engages representatives of the partner organizations and provides vision as well as strategic direction; (d) partnership agreements are created to articulate the roles and responsibilities of different players; and (e) a secretariat function is provided by a third party organization or individual. Surman equated this secretariat function to the role of an executive director for the partnership and indicated that when the secretariat or executive director came from within one of the partners, the individual would need to attempt to detach themselves from their own organization and take on a third-party, servant leadership role.

\section{Putting the Pieces Together}

The three university-community partnership paradigms described above require different administrative structures, employ different strategies and processes, and often focus on impacting different community or university outcomes. As universities and their respective regional communities sought to collaborate during the first two decades of the $21^{\text {st }}$ century, their efforts were often bogged down by the lack of an explicit shared understanding of the partnership paradigm or paradigms being employed. Consequently, university and community leaders must understand the aims, benefits, and differences of each paradigm and discuss with each other the paradigm(s) being used.

USU's and their communities have often collaborated to reform education with the aim of positively impacting regional communities. However, the national landscape has shifted in the area of education reform, further impeding the success of university-community partnerships to impact community educational outcomes, because collaborating organizations often operated from different education reform perspectives.

Following the section below on education reform movements, we provide a case study that illuminates the path taken during the past ten years by one USU and its regional partners to address regional education reform. The case study focuses on the evolution of several different university-community partnership paradigms, including a collective impact paradigm, to improve educational outcomes across a metropolitan region. 


\section{Education Reform Movements in the United States}

Institutions of higher education have long been involved with education reform. Education reforms are intended to change policies, processes, and practices to improve education outcomes and to address the needs of society, including workforce preparation.

Patterson (2011) describes three major waves of education reform in the United States beginning in the 20th century: the progressive education reform, equity-focused reform, and excellence reform waves. Progressive education reforms began in the 1950s with the expansion of college access resulting from the GI Bill and the nation's focus on math and science achievement over Cold War concerns. The Civil Rights movement of the 1960s marked a shift in focus to more equitable education access and the reduction of disparities in educational outcomes across citizen groups. This equity-focused education reform movement included programs, such as the federal government's TRIO grants program (to increase access to higher education for economically disadvantaged students), and the Higher Education Act of 1965 (HEA) (Pub.L. 89-329). In the 1980s, education reform focus shifted to excellence and accountability. The 1983 report, $A$ Nation at Risk, raised fears across the country that the United States had lost its global competitive edge (Patterson, 2011).

Education pipeline can be considered a fourth reform movement. Pipeline reform emerged in the 1990s in response to a fragmented education system in the United States. Early childhood, K-12, and higher education have historically been treated as three separate systems in the United States, creating isolation and misalignment that negatively impacts students. The All One System report by Harold Hodgkinson (1985) provided language to a new P-20 reform movement that would seek to smooth student transitions from preschool (P) to graduate school (20). The pipeline reform movement also represented a shift from a programmatic reform model to a systemic change model (Edmondson \& Zimpher, 2014). By 2006, 46 states had articulated P-20 agendas or formed P-20 councils (Lawson, 2010). These advisory bodies focused on aligning expectations for readiness, access, attainment, data integration, and funding. At a state level, the movement led to the creation of longitudinal data systems, completion programs and partnerships, and curriculum alignment initiatives. State P-20 councils were often advisory, initiated by an elected official, and lacked the supportive infrastructure. These conditions led to significant mission-related, political, legal, constituent, bureaucratic, and resource barriers for the councils (Rippner, 2014). Cross-sector councils that included partners from outside education also formed within communities and regions, and these cross-sector councils experienced many of the same barriers. The P-20 pipeline movement also sought to improve cross-sector coordination by creating what has sometimes been referred to as wraparound services (Kania \& Kramer, 2011). Unfortunately, the broader P-20 pipeline movement lacked unifying goals and often did not identify measurable results. It wasn't long before the P-20 pipeline movement began to lose momentum.

A fifth educational reform movement, called the relevance movement, emerged in the 2000s with a national focus on college and career readiness. Societal concerns about higher education relevance and costs, and the rise of mid-skill jobs as the nation emerged from the 2008 Great Recession led to a renewed emphasis on the roles of community colleges, apprenticeships, and other industry-recognized credentials. P-16 or P-20 labels were problematic because they 
reflected a bias towards four-year institutions as the ultimate educational path. In response, some reform groups began to call for cradle-to-career partnerships. However, the perceptions and focus of community leaders, who had been engaged with the P-20 reform movement for more than a decade, were more difficult to change than the movement's name.

The cradle-to-career partnership in Cincinnati (Strive Partnership) received national attention following the publication of Kania and Kramer's (2011) article on collective impact. In 2006, Nancy Zimpher, then president of the University of Cincinnati, convened a cross-sector group of partners to discuss a new college readiness program. By the end of the meeting, the community leaders were in agreement that more programs were not the answer-the system had to change. What set this cradle-to-career pipeline group apart from many of the previous P-20 councils was that it established specific measurable outcomes that it wanted to improve, created shared and individual accountability to achieving those outcomes, and tapped a readiness from leaders to use their authority to accelerate change (Edmondson \& Zimpher, 2014). Strive Partnership also funded a dedicated staff to coordinate those collective actions. Jeff Edmondson was hired as the executive director for the local partnership, and the partners began to discover what functions were needed to support this type of collective impact work, including data and communication management.

Cincinnati began to see early improvement in the educational outcomes of its students, and Zimpher began talking around the country about what conditions were needed to enable a cradleto-career partnership to succeed. With only one emerging case study, replication was needed to build a robust framework. In 2009, three other communities were identified to test the cradle-tocareer pipeline approach to system reform with funding though Living Cities and from Urban Serving Universities (USU). Richmond, Virginia was selected as one of those three pioneer communities. Four pillars shaped this early work: (a) shared community vision; (b) evidencebased decision making; (c) collaborative action; and (c) investment and sustainability.

The pioneer sites began to identify elements of civic infrastructure that were needed for the initiative to develop, and for their partnerships to emerge and mature. Learning from success and failure was captured in a developmental framework that became known as the Theory of Action. StriveTogether (https://www.strivetogether.org/), the emerging network of cities seeking to replicate the Cincinnati framework for building cradle-to-career civic infrastructure, grew quickly. After several years of testing the Theory of Action, the StriveTogether network implemented quality-assurance measures. Communities that wanted to join the network were required to demonstrate that they had moved beyond an exploring phase of development. Today there are over seventy partnerships, most of them anchored somewhere other than at a higher education institution.

\section{Putting the Pieces Together}

Significant evolution within the U.S. education reform movement has occurred during the last half-century. The most recent national education reform movement addresses societal concerns over college and career readiness and has been labeled the cradle-to-career pipeline movement. Cradle-to-career partnerships have drawn national attention, because of the early improvements 
to regional educational outcomes being realized in Cincinnati, Ohio, where a collective impact paradigm is being used to realize cradle-to-career education reform goals.

The case study below describes the pioneering work of Virginia Commonwealth University (VCU) in the Richmond, Virginia using a cradle-to-career framework. The case study describes changes that occurred over a ten-year period in the university's role as founder and universitycommunity partnership collaborator, and documents a shift in understanding and approach to partnership that exemplifies the collective impact paradigm.

\section{Case Study: Richmond, Virginia and Virginia Commonwealth University}

Virginia Commonwealth University (VCU) was an early participant in the community engagement movement, formally creating the Division of Community Engagement (DCE) in 2006. Over the next 10 years, student service hours in the community increased from 346,526 to $1,462,854$, with a $162 \%$ increase in service-learning class sections. Across that decade, the DCE supported faculty members in developing service-learning courses and community-based research projects. In 2012, it launched ASPiRE, VCU's first living-learning residential hall with a focus on community service. The Division delivers community outreach programs through the Mary and Frances Youth Center, including a regional youth program quality initiative, and direct youth programs. The DCE also created and still leads the university's Council for Community Engagement, which seeks to create a culture of community engagement across the university. VCU is recognized as a community-engaged institution by the Carnegie Foundation, and it is one of only 54 universities to be designated as "Community Engaged" with "Very High Research Activity”.

VCU also became an early participant in the anchor institution movement. The university has played an active role in identifying and refining national and Richmond-specific indicators that can be used to align the university's assets to contribute to measurable regional outcomes. VCU has long been recognized as an anchor in Richmond, Virginia. It has even been recognized in 2002 by CEOs for Cities and the Initiative for a Competitive Inner City for using its presence in Richmond to encourage urban revitalization. In 2006, VCU was ranked eighth in the top 25 "Best Neighbors" in the New England Board of Education report, Saviors of Our Cities.

Today, VCU distinguishes itself as a “...premier urban, public research university...” with a mission to “...advance knowledge and student success...” through several commitments including "sustainable, university-community partnerships that enhance the educational, economic, and cultural vitality of the communities VCU serves...” (VCU Strategic Plan, 2011). For well over 100 years, the university has been deeply engaged with the community to address complex social problems. Like in most institutions of higher education, these activities developed primarily through individual academic departments. The following figure provides a visual representation of some of transitions in the role of VCU in their community benefit efforts. 


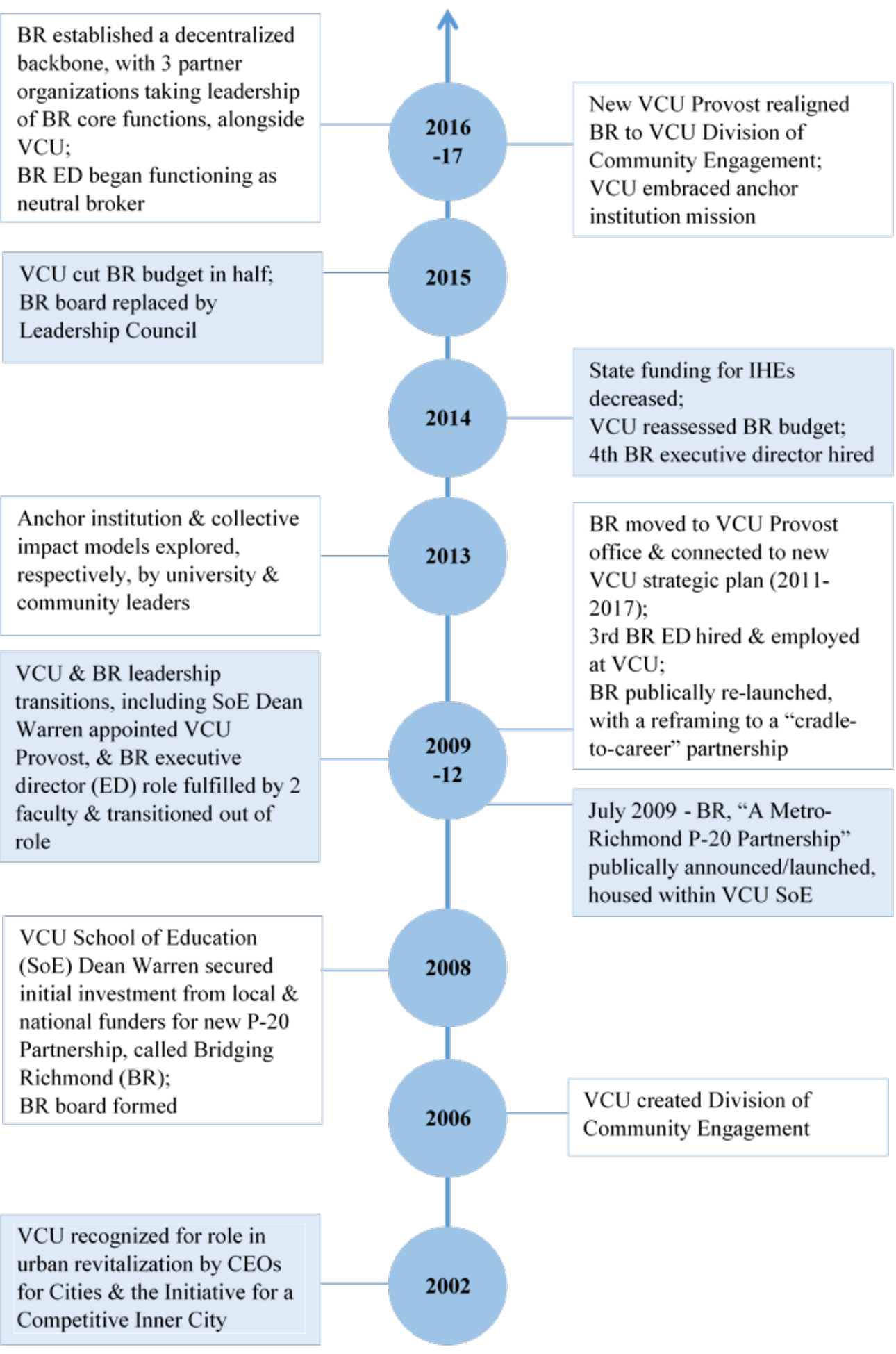

Figure. Timeline in University Roles 
VCU: Evolving to include a Collective Impact Paradigm

Already one of the city's largest employers, VCU greatly expanded its physical footprint, degree programs, and student enrollment during Eugene P. Trani's two decades as president (19902009). President Trani was determined to show how a university could collaborate, particularly to catalyze economic development. From 1997-1998 he chaired the Greater Richmond Chamber of Commerce, and from 2001-2004 he chaired Richmond Renaissance, which focused on downtown revitalization (now Venture Richmond, http://www.venturerichmond.com/). Trani (2008) urged public and private higher institutions to see higher education connections to communities as "essential to our core functions and are increasingly vital to our continued success as well as the long-term prosperity of the nation's cities, regions, and states”.

President Trani, a founding member of the Coalition of Urban Serving Universities (USU), was aware of a Living Cities (https://www.livingcities.org/) grant opportunity. In 2009, VCU School of Education Dean Bev Warren submitted a proposal and Richmond was chosen as an inaugural member of the Education Partnership Implementation Network. This network was based on the early success of the Strive P-20 partnership, referenced earlier in this article, in Cincinnati, Ohio. The other three sites in the network were California State University, East Bay; Indiana University-Perdue; and University of Houston. This VCU presidential initiative, championed by Dean Warren, would require buy-in beyond the university.

After securing the initial investment from USU and Living Cities, Warren sought additional investment from the community. Altria, the holding company for Phillip Morris with headquarters in Richmond, had recently made significant investments in another national program to improve educational outcomes, entitled Readyby21 (http://www.readyby21.org/). Almost simultaneously, Richmond became a project site for both fledgling models. Resolute, Warren secured initial investment from Strive, Readyby21, Altria, The Community Foundation, and the Jessie Ball DuPont Foundation, for the P-20 partnership that would be called Bridging Richmond.

Warren began meeting with community leaders to introduce the concept and to invite them to join an executive council, a CEO-level board that would inform how to move Bridging Richmond forward. Founding members included the superintendent of the Richmond City Public Schools and presidents of the Chamber of Commerce, Community Foundation, community colleges, private colleges, and executives from large corporations. The executive council participated in presentations on the USU model as well as by CEOs for Cities, which was launching the Talent Dividend project to increase college attainment in the top 51 metro areas. From the beginning, the group was focused on improving economic competitiveness by working back from the business sector to workforce preparation.

Bridging Richmond: 2009-2012

Bridging Richmond, “A Metro-Richmond P-20 Partnership”, was announced in July 2009 in a high-profile, public event. At the time, Virginia Commonwealth University and the broader higher education community were still primarily operating from the community engagement paradigm. A few states and regional leaders were beginning to consider the implications of the P- 
20 reform movement, while others were focused on the accountability excellence movement. Consequently, the earliest expression of Bridging Richmond reflected this cross-section of stakeholder perspectives and paradigms.

Virginia Commonwealth University established the Division of Community Engagement in 2006 with a vision of becoming a national model for community engagement and regional impact. In 2009, the university was making strides towards integration of community engagement through teaching, research and outreach programs. When the university was accepted as an Education Partnership Implementation Network, university leaders created the P-20 partnership within the context of this community engagement paradigm. Bridging Richmond was initially housed within the Center for School Improvement, effectively creating a community engagement hub within the VCU School of Education. Being situated in a School of Education center influenced the types of problems and solutions that arose. Dean Warren made the case for the new partnership in the Spring/Summer 2009 edition of The Bridge, the magazine of the School of Education. The letter from the dean that opened the magazine emphasized the "outstanding work of the School of Education community" through new programs and leadership roles that foster strong partnerships”. As it stood in 2009, Bridging Richmond reflected a P-20 reform initiative that operated primarily through a community engagement paradigm.

Universities have historically played a key societal role in generating and sharing knowledge about best practices. These traditions led to VCU's Bridging Richmond role as founder and early carrier of the P-20 reform vision. A shared vision or shared agenda had to be created. Some of the community leaders who became involved with the Bridging Richmond initiative would later express the opinion that convening the initiative at a public launch under the bright media spotlight inhibited their ability to ask questions and fully understand the purpose, goals, and roles of Bridging Richmond executive council membership. VCU and the other inaugural members of the Education Partnership Implementation Network were simultaneously co-creating the partnership vision nationally while simultaneously trying to communicate that vision to local leaders from multiple sectors.

Establishing a centralized backbone model within the university was pragmatic because the university was the primary holder of the vision, and the 'university as driver' approach was consistent with the community engagement paradigm. This primary role of the university in the early days of Bridging Richmond impacted the role of the partnership's first director. Bridging Richmond's first director was the executive director of the VCU School of Education's Center for School Improvement. She was also the primary investigator for a \$5.2 million federal grant to recruit, prepare, and retain school leaders in hard-to-staff schools. This first Bridging Richmond director retired after one year of fulfilling these multiple roles, and a second Bridging Richmond director was hired who also had considerable experience in the K-12 and higher education sectors. The role and skill sets of these first two Bridging Richmond directors aligned with traditional research faculty roles within the academy.

Systems within and beyond the university had considerable impact on Bridging Richmond's early activity and challenges. The national convergence of the community engagement paradigm and P-20 reform movement has already been noted. Regional leaders within the Richmond community were being asked to apply two national collaboration models simultaneously (Strive 
and ReadyBy21). The implementation of these two national collaboration models could be considered complementary. However, the politics and jargon associated with each of them made it challenging for community leaders to articulate a common agenda and vision locally across the two models. Within VCU, President Trani retired weeks after the public launch of the Bridging Richmond partnership, and President Rao became the chair of the fledgling initiative. Dean Warren was named the interim provost in April of 2010 and became provost in April 2011. An interim dean for the School of Education was appointed from April 2010-June 2012. Bridging Richmond quickly became thought of as the initiative of a former president during a time of significant university-wide and School of Education specific leadership change.

The second Bridging Richmond director resigned by the end of 2011. Community leaders were impatient with what was perceived as getting caught up in process with no results. Some sectors within the community continued to relate to the accountability and excellence reform movement. Bridging Richmond, a P-20 reform movement project, continued to be perceived as a VCUdriven program with a bias towards bachelor's degrees. The relevance reform movement was building, and additional emphasis nationally and regionally was being placed on the role of community colleges and post-secondary learning leading to associate degrees, apprenticeships, and other industry-recognized credentials. Leadership churn and an emerging, rather than a clear and well-established, project vision meant Bridging Richmond lacked the energy and influence to change regional and university dynamics that were at the time being driven by individual interests, action, and recognition. It was time to reassess the vision and viability of the P-20 reform movement in Richmond.

Bridging Richmond: 2012-2014

Virginia Commonwealth University hired a consultant and a transition team was formed to determine how and if Bridging Richmond should move forward. The university also completed its strategic plan: Quest for Distinction: Discover, Impact, Success. The new plan articulated university-community partnerships as critical and targeted K-12 education, health access, and economic development as key partnership focus areas. Provost Warren was able to connect the Bridging Richmond partnership to this new VCU strategic agenda, moved Bridging Richmond to the Office of the Provost, and launched a national search for a new executive director. In August 2012, Bridging Richmond was re-launched in another large public event. The $P$-20 reform language was intentionally dropped, and a new cradle-to-career reform language was emphasized.

From 2012-2014, the nation and region lost momentum for the community engagement paradigm. Businesses, hospitals, and higher education began to reinterpret the social contract in response to post-recession fiscal austerity. The university, and some community leaders, started to learn about the anchor institution paradigm. The community outside the university became interested in collective impact models and quickly launched several local collective impact initiatives. The accountability and excellence education reform movement remained a dominant frame, and leaders also began to incorporate relevance reform movement values. As part of a federal Promise Neighborhood grant application, community leaders had been learning about Results Accountability, as described in Mark Friedman's (2005) Trying Hard Is Not Good Enough. The community focused on technical solutions, by purchasing licenses for population 
indicator dashboards, as well as case management software for linking performance measures. The community had not invested equally in building trust and shared measurement for the shared data systems, and Bridging Richmond was able to fill that void.

Bridging Richmond convened a Regional Data Advisory Committee with people from business, philanthropy, K-12, and higher education to select core, lagging education indicators for the partnership. Bridging Richmond partnership staff members developed impact frameworks for two of the new intermediaries that: (a) clarified the desired result and indicators; and (b) identified shared measures that could be used by multiple partners to align practices for shared action. The Bridging Richmond partnership also commissioned an economic study to identify areas of high occupational demand for the region through 2030. The partnership set a regional degree and credential goal based on the projected demand, and Bridging Richmond convened 31 partners to co-develop a Department of Labor (DOL) grant proposal that focused on high school reform to address high demand for information technology and computer science occupations. Job analysis and curriculum alignment across K-12, apprenticeship, and two- and four-year colleges continued even though the grant proposal was not funded.

Virginia Commonwealth University, through the Office of the Provost, continued to serve as a centralized backbone for the partnership. During the period, the partnership staff grew to include an executive director, manager of evidence based decision making, and communications coordinator with funding for these positions coming almost exclusively from the university. The role of the university as anchor and primary investor allowed the Bridging Richmond to keep its doors open through multiple internal transitions and periods of limited local financial investment. VCU and community leaders began to explore the possibility of forming a separate 501(c)3, developed bylaws, and renamed its executive council a "board of directors" in order to shift the perception of Bridging Richmond in the community from 'university program' to 'partnership' and to improve financial sustainability.

The executive director for Bridging Richmond now had one foot in and one foot out of the university. The executive director was responsible to a board of directors and executive council that had no fiduciary responsibility, and directly reported to the founder of the work within an institution providing fiscal agency, primary investment, and founding vision. During this period, the executive director's role was to help the community develop a common agenda through shared measurement, demonstrate the relevance of the work by bringing multiple partners together to take shared action, and fund development. Examples of this emphasis included cochairing a regional workforce preparation group for another emerging regional collaborative to propose a shared agenda for education and career readiness, and writing a successful Lumina Foundation Community Partnership for Attainment grant.

Two significant systems dynamics were at play during this period. First, the system in Richmond was designed to promote individual transactions and a competitive agenda that drove a direct service delivery expectation. Shared accountability to results through aligned contributions from the partners was not the solution that community leaders were expecting. Partners sought program proposals that might benefit their own individual organizations so that each could decide whether or not to participate and/or fund the initiative. Otherwise, they preferred to work 
on their own organizational improvement internally, without peer accountability through a partnership, or incursion from what was still perceived by many as a university program.

Significant system dynamics also existed within Virginia Commonwealth University. Virginia's funding for higher education fell by over 20\% from 2007 to 2013, making it one of the lowest per FTE student in the nation. The university had been rapidly expanding before and during this period. Through the Quest for Distinction, the university had focused on improving educational quality, embracing diversity, developing the research program with substantial increases to external funding, pre-eminent academic programs, and growing the alumni base and engagement of the community.

In July 2014, Provost Warren was appointed as president of Kent State University. An interim provost was named, and one of his first charges was to identify ways the University could respond to significant state funding cuts. Bridging Richmond, an initiative started by a former president and provost, was one place where university cost savings could occur without impacting internal operations. Presentations were made to the Bridging Richmond board of directors, calling on the community to demonstrate an increased investment or the university would reduce its financial investment by half. VCU appointed Bridging Richmond's manager of evidence-based decision-making as the partnership's fourth executive director after the third executive director left VCU to accept a position with the Carnegie Foundation. With prior experience in nonprofit administration, community health, and the faith community in Richmond, the new Bridging Richmond director brought skills and relationships from sectors beyond higher education. In its first 4 years, the fledgling Bridging Richmond partnership had employed four executive directors.

Bridging Richmond: 2015-2017

Virginia Commonwealth University’s interim provost charged the Bridging Richmond executive director with accelerating the partnership toward shared action and revising the partnership's accountability structure to reflect VCU as the anchor and primary investor. In response, the executive director put forward three proposals to the interim provost and executive committee: (a) wind the partnership down over three months; (b) finish its largest grant and wind down over 14 months; and (c) identify a primary customer and champion for the next year to provide focus and value. Regional K-12 school superintendents came forward to express interest in being a primary customer and Bridging Richmond champion for the next year, as they prepared for a regional equity summit intended to lead to shared action. VCU's financial contribution to the partnership budget was cut in half, the Bridging Richmond's board was dissolved, and all community leaders were considered for the positions on the partnership's leadership council. Consideration was based on their organization's aligned actions or the funding their organization contributed towards shared action. VCU administrative leaders determined that Bridging Richmond was unique and valuable in its role as a neutral broker of community collaboration. The university provided a one-time cash payment to give the partnership time to implement its proposals.

VCU hired a new provost in March 2015. The VCU Office of Planning and Decision Support and the Division of Community Engagement developed a pilot anchor framework for 
understanding the impact of the university in 2015. An anchor dashboard task force was formed and co-chaired by these same two offices. VCU celebrated the Division of Community Engagement's $10^{\text {th }}$ anniversary in 2016. The Division of Community Engagement also developed a partnership mapping program to better understand the landscape of university activity in the community and to better identify opportunities for matching community and university partners. After considering various administrative home options for Bridging Richmond within the university, the new provost selected the Division of Community Engagement. VCU was simultaneously investing in the community engagement paradigm, anchor institution, and collective impact paradigms while seeking to clarify connections and roles between the potentially complementary approaches.

Bridging Richmond continued to build on the momentum in the community for collective impact and results accountability. The partnership also obtained, for the first time, regional kindergarten readiness data for its early childhood coalition at the school-level, disaggregated by race, ethnicity, socioeconomic status, and sub-scores. These data allowed the early childhood coalition to target preschool quality interventions, based in a way that had never been possible with only district-wide scores. Partnership staff developed shared data system prototypes for collective impact initiatives to coordinate middle school out-of-school time and college and career centers in the city schools. Bridging Richmond provided operational support for data use in one of the partnership's coordinating organizations, and oversaw transition of the data to a third party vendor. The system used the shared measurements that came from the facilitation of the impact framework and allowed for connecting school and multiple nonprofit data.

Because of these accomplishments, the Richmond City Public School district invited Bridging Richmond to embed a staff member within the district to provide data support. Federal financial aid information (FAFSA) was made available in week-over-week and year-over-year dashboards at the high school level for the first time in the state. Improvement teams were formed and provided with continuous improvement coaching to use the data, as well as policy advocacy to get Virginia to receive the data at a student level. Following up on the unsuccessful Department of Labor (DOL) proposal, the partnership also continued to convene groups of employers to do job analysis on some of the high-demand technology careers, and it convened K-12 and higher education partners to work on curriculum alignment. The governor announced a high school redesign grant, and the superintendents built on the Department of Labor grant proposal. They folded the job analysis and curriculum alignment work into the committees that were formed when the grant was awarded. Collaborative Action Networks were also formed to address chronic absence and elementary literacy. The partnership had moved to shared action and demonstrated the value of backbone functions.

At the beginning of this period, VCU continued to serve as the anchor and centralized backbone for the partnership. As VCU also embraced an anchor institution mission, it became important to clarify the difference between the two roles. An anchor within collective impact is an organization that provides fiscal agency and other core functions for the partnership. The role of the university as the sole anchor for Bridging Richmond began to shift in 2016. There were new executives at The Community Foundation, Robins Foundation, and United Way of Greater Richmond and Petersburg, and they saw the value of the backbone functions. The Bridging Richmond executive director began meeting with each of these new executives to introduce the 
decentralized backbone model and to identify what functions of the partnership each executive might be interested in leading. A nine-month facilitated group conversation followed that resulted in each institution/organization identifying aspects of the partnership they would anchor, and as importantly, what functions they would bless the others to lead.

This process of transitioning to a collective impact paradigm was accelerated when Bridging Richmond's senior data analyst was hired by a local community organization that had been receiving data support through the partnership. Instead of assuming that a new senior data analyst should be hired at VCU, the four organizations were asked where (i.e., within which organization(s)) they wanted to build data capacity for the partnership. The partners decided that United Way would become the primary fiscal agent, host the data infrastructure, and staff some of the partnership's collaborative action networks. VCU would continue to host the executive director, be the secondary fiscal agent, and leverage the Division of Community Engagement to align other university contributions as a partner. The Community Foundation took on leadership of capability building for the convening, facilitation, and leadership skills needed for collective impact. The Robins Foundation, a private family foundation, was well-positioned and interested in forming a policy action team. The partnership executive director role had fully transitioned into a secretariat or servant leadership role for the community leaders, and there was a core group of partners that no longer saw the partnership as a university program.

The system dynamics during 2015-2017 exemplify the emergent, evolutionary nature of collective impact work. Collective impact work cannot depend on a single visionary leader, organization, or single sector. In 2015, the Bridging Richmond partnership could have begun to wind down, returned to being a program within a university center, or been championed by any sector or group of community leaders. In 2015, five of the twelve leadership council members were superintendents, and they served as a magnet for the other members. During the period, all but one of those superintendents transitioned within or outside regional school districts. The new philanthropic leaders, who had become engaged because of the superintendents, began to become customers and champions of the work as school district leadership changes occurred.

Leadership transitions at VCU, and ambiguity about how the partnership would connect to other university priorities, provided a great deal of autonomy and urgency for the executive director to deepen the engagement of community partners. Responding to multiple emerging collaborative initiatives that were priorities for community leaders provided Bridging Richmond with sustainable funding during the transition and proof of concept for the value of the backbone functions. If Bridging Richmond had treated the community as static, and failed to respond to any of these environmental conditions, the partnership would have likely become extinct.

Instead, multiple partners began to own the work and change a small part of the system in Richmond. United Way of Greater Richmond and Petersburg redesigned their communications, community indicator project, and activities to better align to the cradle-to-career reform continuum. The Robins Foundation updated their strategic plan to incorporate partnership indicators and made changes to funding priorities. The Smart Beginnings early childhood coalition re-aligned with the Bridging Richmond partnership and began incorporating practices supported by the backbone organizations. 
Instead of a staff of one to three people at VCU, the Bridging Richmond partnership "staff” quickly expanded to include nine leaders from seven partner organizations, who began meeting monthly to align the work of their organizations and the functions of the partnership they led. Alongside a more stable community leadership for the partnership, the current executive director has been in role for three years and worked for the partnership a total of four and a half years, whereas the average tenure for each of the previous three executive directors was 16 months. Developing relationships, trust, awareness of multiple motivations, leadership without formal authority, and ability to navigate the politics of a regional system requires time and development of a unique skillset. While attribution of changes in lagging education and workforce indicators is not possible yet, there is considerable evidence that systems are changing in a way that could contribute to those desired results.

\section{Ten Takeaways}

Based on our experiences at an urban serving university that has recently evolved a collective impact partnership paradigm, while continuing to use both the community engagement and anchor institution partnership paradigms, we offer the following ten takeaway observations. These observations are designed to help university leaders successfully engage with universitycommunity partnerships, particularly collective impact partnerships that realize beneficial outcomes for universities, as well as for the regional communities within which they operate.

1. Urban serving universities have shifted from co-existing alongside their communities towards reciprocity, an exchange for mutual benefit.

2. While important, these transactions must be complemented with system transformations within the higher education context and in the broader community, if we are to realize improved social outcomes.

3. Community engagement, anchor institution, and collective impact are three paradigms for university-community benefit that can be complementary if coordinated and applied to appropriate community and university problems.

4. The first major obstacle to a successful collective impact process are that partners expect the wrong type of solutions.

5. The second is that universities, as knowledge organizations, may overlook how their own research and community engagement norms impact the types of solutions they value and bring to the community.

6. The problem, desired result, and the current capability of partners to share leadership must inform the boundaries of roles and tasks for the university partner.

7. Collective impact partnerships require strong backbone support functions that can be either centralized in one organization or decentralized across multiple partners.

8. Historical and contemporary university-community power dynamics make it difficult for higher education institutions to serve as a neutral broker for collective impact.

9. If the university must host the executive director for a collective impact partnership, the institution needs to ensure that this leader is able to detach themselves from the university and take on a third-party, servant leadership role.

10. The executive director role in collective impact partnership requires sophisticated leadership skills to facilitate a shared vision, cultivate trust and peer accountability, navigate community politics, communicate across multiple sectors and leadership levels, understand the 
motivations of and value to partners, build a cross-functional team, and use informal authority to mobilize partners for shared action.

\section{Conclusion}

University leaders, particularly in times of fiscal uncertainty, may be tempted to "reduce investment in activities that are sometimes considered tangential to our core missions of teaching, research, and service” (Trani, 2008, p. 1). Particularly for urban and metropolitan universities, the mission of community benefit is not a luxury or a tangential activity, it is core to the identity of the institutions, valuable to the other core mission elements, and essential to the vitality of the surrounding communities. Neither the communities nor the universities are static, but are always evolving individually and in relationship with each other. University and community leaders must embrace the paradox that Kania and Kramer describe as "combining intentionality (that comes with the development of a common agenda) and emergence (that unfolds through collective seeing, learning, and doing)” (2013, p. 8).

Universities are collaborating with community partners to increase their intentionality through anchor dashboards and community engagement efforts that identify clear results with measurable targets. Understanding the current landscape of university-community partnerships is important work, as are efforts to more intentionally align existing and new university activity towards clear aims. At the same time, leaders must be vigilant to insure that predetermined solutions do not crowd out new ways of collaborating to address complex and adaptive problems. Improving systems so that they move beyond incremental change to transform communities requires leaders who are comfortable with continually unfolding opportunities, strategies, and relationships, and who have the endurance to persevere through the inevitable periods of failing forward. Without the founding vision and persistent investment of Virginia Commonwealth University, it is likely that Bridging Richmond would never have been created or survived the many university and community transitions that occurred.

In this article we suggest that universities must embrace emergence and be as intentional about clarifying their role as they are in developing a common agenda. A key takeaway from this article is that higher education "need not always be involved in, much less at the forefront of, community engagement work” (Whitney, Harrison, Clayton, Muse, \& Edwards, 2016, p. 88). It is also important that university leaders be consciously aware that the current system is aligned to deliver the current results. Intentional and thoughtful force must be applied to keep the system from recreating itself by shifting from isolated programs to isolated collective impact initiatives. We invite you to reread and reflect on the ten takeaways preceding the conclusion section, to add your own learning, and to identify specific actions that your institution can take to improve its community benefit in the next month, three months, and year. 


\section{References}

Bridging Richmond: A metro-Richmond p-20 partnership. (2009, Spring/Summer). Bridge: The Magazine of the VCU School of Education, 14-17.

Butin, D. W., \& Seider, S. (Eds.). (2012). The engaged campus: Majors, minors, and certificates as the new community engagement. New York, NY: Palgrave Macmillan.

https://doi.org/10.1057/9781137113283

Cantor, N., Englot, P., \& Higgins, M. (2013). Making the work of anchor institutions stick: Building coalitions and collective expertise. Journal of Higher Education Outreach and Engagement, 17(3), 17-46. Retrieved from http://openjournals.libs.uga.edu/index.php/jheoe/article/view/1036

Cantor, N. \& Englot, P. (2014). Civic renewal of higher education through renewed commitment to the public good. In J.N. Reich (Ed.), Civic Engagement, Civil Development, and Higher Education. Retrieved from http://archive.aacu.org/bringing_theory/documents/4civicseries_cecd_final_r.pdf

CEOs for Cities with Living Cities. (2010). How to behave like an anchor institution. Retrieved from https://ceosforcities.org/how-to-behave-like-an-anchor-institution/

Dr. Eugene P. Trani biography. (2016). Retrieved from http://eugenetrani.vcu.edu/bio.html

Dubb, S., McKinley, S., \& Howard, T. (2013). The anchor dashboard: Aligning institutional practice to meet low-income community needs. Retrieved from https://democracycollaborative.org/content/anchor-dashboard-aligning-institutional-practicemeet-low-income-community-needs-0

Edmondson, J., \& Zimpher, N. L. (2014). Striving together. Albany: SUNY Press.

Fitzgerald, H. E., Bruns, K., Sonka, S., Furco, A., \& Swanson, L. (2012). The centrality of engagement in higher education. Journal of Higher Education Outreach and Engagement, 16(3), 7-28. Retrieved from http://openjournals.libs.uga.edu/index.php/jheoe/article/view/861

Friedman, M (2005). Trying hard is not good enough. Santa Fe: FPSI Publishing.

Futrell, M. H. (2010). Transforming teacher education to reform America's P-20 education system. Journal of Teacher Education, 61(5), 432-440.

https://doi.org/10.1177/0022487110375803

Hanleybrown, F., Kania, J., \& Kramer, M. (2012 January 26). Channeling change: Making collective impact work. Stanford Social Innovation Review, 20, 1-8. Retrieved from https://ssir.org/articles/entry/channeling_change_making_collective_impact_work 
Hensley, B., Galilee-Belfer, M, \& Lee, J. (2013). What is the greater good? The discourse on public and private roles of higher education in the new economy. Journal of Higher Education Policy and Management, 35(5), 553-567. https://doi.org/10.1080/1360080X.2013.825416

Hodgkinson, H. L. (1985). All one system: Demographics of education, kindergarten through graduate school. Washington, D.C.: Institute for Educational Leadership. Retrieved from http://files.eric.ed.gov/fulltext/ED261101.pdf

Kania, J., \& Kramer, M. (2011). Collective impact. Stanford Social Innovation Review, 9(1), 3641. Retrieved from https://ssir.org/articles/entry/collective_impact

Kania, J., \& Kramer, M. (2013 January 21). Embracing emergence: How collective impact addresses complexity. Stanford Social Innovation Review. Retrieved from https://ssir.org/articles/entry/embracing_emergence_how_collective_impact_addresses_complexi ty

Lawson, H. A. (2010). Needs and opportunities for social work leadership in emergent P-16 initiatives. Children \& Schools, 32(1), 51-60. https://doi.org/10.1093/cs/32.1.51

Lockeman, K. \& Pelco, L. E. (2013). The relationship between service-learning and degree completion. Michigan Journal of Community Service-Learning, 20(1), 18-30. Retrieved from http://files.eric.ed.gov/fulltext/EJ1047041.pdf

Patterson, R. R. (2011). The development of a P-20 educational campus: A case study on innovation (Doctoral dissertation). University of Denver, Denver, CO. Retrieved from http://digitalcommons.du.edu/etd/499/

Rippner, J. A. (2014). State P-20 councils and collaboration between K-12 and higher education. Educational Policy, 31(1), 3-38. https://doi.org/10.1177/0895904814558008

Senechal, J., \& Stringer, J. (2014). Middle level learning: Compendium of research and best practice. Richmond: Metropolitan Educational Research Consortium. Retrieved from http://scholarscompass.vcu.edu/merc_pubs/6/

Starke, A., Shenouda, K., Smith-Howell,D. (2017). Conceptualizing community engagement: Starting a campus-wide dialogue. Metropolitan Universities, 28(2), 72-89. https://doi.org/10.18060/21515

Surman, M., \& Surman, T. (2008). Listening to the stars: The constellation model of collaborative social change. Social Space, (Annual), 24-29. Retrieved from https://socialspacemag.org/wp-content/uploads/2016/12/SocialSpace-2008.pdf

Trani, E. (2008). Even in hard times, colleges should help their communities. Chronicle of Higher Education, 54(36), A36. Retrieved from http://www.chronicle.com/article/Even-in-HardTimes-Colleges/23564 
VCU strategic plan: Quest for distinction (2011). Retrieved from https://quest.vcu.edu/

Whitney, B., Harrison, B., Clayton, P. H., Muse, S., \& Edwards, K. E. (2016). Learning from and with community organizations to navigate the tensions of democratic engagement. Michigan Journal of Community Service Learning, 23(1), 85-91.

https://doi.org/10.3998/mjcsloa.3239521.0023.108 


\section{Author Information}

* Jason W. Smith, PhD, is the partnership executive director for Bridging Richmond and an administrative and professional faculty member in the Division of Community Engagement at Virginia Commonwealth University.

Jason W. Smith

Division of Community Engagement, Bridging Richmond

Virginia Commonwealth University

901 West Franklin Street

Box 842527

Richmond, VA 23284

Email: smithjw4@vcu.edu

Telephone: 804-828-3909

http://www.linkedin.com/in/jason-smith-469354a7/

Lynn E. Pelco, $\mathrm{PhD}$, is the associate vice provost of community engagement in the Division of Community Engagement at Virginia Commonwealth University and holds a joint faculty appointment as professor in the VCU School of Education.

Lynn E. Pelco

Division of Community Engagement

Virginia Commonwealth University

901 West Franklin Street

Box 842527

Richmond, VA 23284

Email: lepelco@vcu.edu

Telephone: 804-827-8215

https://www.linkedin.com/in/lynn-pelco-b819613b/

Alex Rooke is the network coordinator for Bridging Richmond, hosted by the Division of Community Engagement at Virginia Commonwealth University.

Alex Rooke

Division of Community Engagement, Bridging Richmond

Virginia Commonwealth University

901 West Franklin Street

Box 842527

Richmond, VA 23284

Email: acrooke@vcu.edu

Telephone: 804-827-4581

https://www.linkedin.com/in/alexandra-rooke-52297118

*Corresponding author 